\title{
Students' Perceptions of the Effectiveness of Their Homeroom Teachers' Leadership and Classroom Management at Vocational High Schools
}

\author{
Chin-Chang Wu, Fang-Pin Lai, Chia-Ling Shih, and Chin-Wen Liao
}

\begin{abstract}
This study explores how Vocational High School students perceive their homeroom teachers' performance in leadership and classroom management. The conclusions from these are below: 1) Homeroom teachers from central Taiwan's Vocational High Schools usually strengthened their leadership through encouragement, but seldom through charismatic influence. 2) Out of all the effective classroom management perspectives, the aforementioned teachers performed best in classroom discipline, but needed to improve the classroom climate. 3) The female freshmen and sophomores majoring in business or home economics at the aforementioned Vocational High Schools, was the subgroup that had more favorable perceptions of their homeroom teachers' leadership. 4) The female freshmen and sophomores majoring in business or home economics at the aforementioned Vocational High Schools was also the subgroup that had more favorable perceptions of their homeroom teachers' classroom management effectiveness. 5) There is a significantly positive correlation between the aforementioned homeroom teachers' charismatic influence and teacher-student interactions. 6) The best predictor for the aforementioned homeroom teachers' effective classroom management was charismatic influence.
\end{abstract}

Index Terms-Vocational high school students, homeroom teachers, classroom-teacher leadership, classroom management effectiveness.

\section{INTRODUCTION}

\section{A. Research Background and Motivations}

Education paves the way, not only for improvement in national competitiveness, but also for personal growth, social progress and mankind's sustainable future. In their efforts to improve education, governments around the world have scrambled to emphasize a grassroots classroom management style for teachers. Classroom management is a topic that sparked an academic enthusiasm that began in 1970, and after 1990 inspired a series of studies across Taiwan [1] and remains a much-discussed issue to this day. The changing Taiwanese family structure was first reflected in a declining birthrate, which subsequently brought an increased emphasis on children's' education, along with constant reforms, that then led to new education policies (e.g., the "multiple approaches to college admissions" program, 12-year

Manuscript received March 8, 2014; revised May 15, 2014.

The authors are with the Department of Industrial Education and Technology at National Changhua University of Education (NCUE), Taiwan (e-mail: wcc1102@yahoo.com.tw.com, tcwliao@cc.ncue.edu.tw, yd3174@gmail.com, yi2323222@yahoo.com.tw). compulsory education, and exam-free admissions). All of which has left parents, students and the general public deeply concerned about, and expecting more, from the quality and performance of the national education system [2]. The chief driving force behind the materialization of the ideals and goals of educational reform, are homeroom teachers, who are also responsible for classroom management - the fulfillment of relevant visions, and leadership. Good classroom management skills are the basic requirement for a homeroom teacher wanting to effectively achieve his/her educational goals [3]. Great importance has been attached to the effectiveness of homeroom teachers' classroom management, from elementary to senior high, and vocational schools. The first goal of this study was to examine how Vocational High School students currently perceive their homeroom teachers' leadership and the effectiveness of their classroom management.

Recent studies on teacher leadership have tended to adopt the two core concepts suggested by Bass [4], transformational leadership and transactional leadership, to illustrate how homeroom teachers lead their classes, while interacting with the students. Studies have also pointed out demographic differences in how Vocational High School students perceive their homeroom teachers' performance in leadership and classroom management. For instance, [5] mentioned a significant difference between schools, and also between the students' current year of study (freshmen, sophomore, etc.), in the students' perceptions of their teachers' effective classroom management. Ref. [6] concluded that students' perceptions of a homeroom-teacher's leadership vary significantly depending on the school being attended, the academic major and level of seniority. Consequently, the second goal of this study was to explore how demographic variables affect the students' perceptions of homeroom-teacher leadership and the effectiveness of their classroom management.

Classroom management has long been an important indicator in the assessment of a teachers' career development. As homeroom teacher competencies directly affect the students' academic performance, a homeroom teacher must be competent in order to maximize the effectiveness of classroom management, which grows proportionally to his/her professional capabilities. Since improving the effectiveness of classroom management is the most visible approach for a homeroom teacher to display his/her expertise, the third goal for this study was to explore the effects of the homeroom teachers' leadership and their classroom management skills. 


\section{B. Research Purposes}

According to the research background and motives, this study was intended to:

1) Find out how Vocational High School students currently perceive their homeroom teachers' leadership and classroom management skills.

2) Explore the demographic differences in the vocational students' perceptions of homeroom-teacher leadership.

3) Examine the demographic differences in the students' perceptions of the effectiveness of their homeroom teachers' classroom management.

\section{RESEARCH DESIGN AND IMPLEMENTATION}

\section{A. Research Method and Process}

The research method and process adopted, in accordance with the research objectives, are stated as follows:

\section{1) Research method}

First a comprehensive theoretical framework was constructed to ensure a successful study, and based on which the perspectives of the homeroom teachers' leadership and classroom management skills were determined. After reviewing relevant literature and questionnaires, a draft questionnaire was compiled. The reliability and validity of the research tools were examined through an expert review, followed by a questionnaire-based survey using random, proportionally stratified cluster sampling. The collected data was sorted and analyzed, and then conclusions and recommendations were proposed. Research procedures show as Fig. 1.

\section{B. Research Framework}

This study intended to explore: how Taiwanese Vocational High School students perceive and are influenced by their homeroom teachers' leadership and the effectiveness of their classroom management; to analyze how their perceptions reflect demographic differences; to explore the connection between the homeroom teachers' leadership and classroom management effectiveness, and whether the former is a good predictor of the latter. This study collected and reviewed literature regarding homeroom teacher leadership and classroom management before compiling a questionnaire for the survey that involved the following variables. 1) The independent variables are demographic ones, including the student's gender, seniority, academic major and school attended; and 2) the dependent variables related to 1.the teachers' leadership (i.e. charismatic influence, individualized consideration, intellectual stimulation, encouragement, contingent rewards and exception management) and, 2.the teacher's classroom management effectiveness (i.e. classroom discipline, teacher-student interaction, classroom climate, learning results and teaching quality).
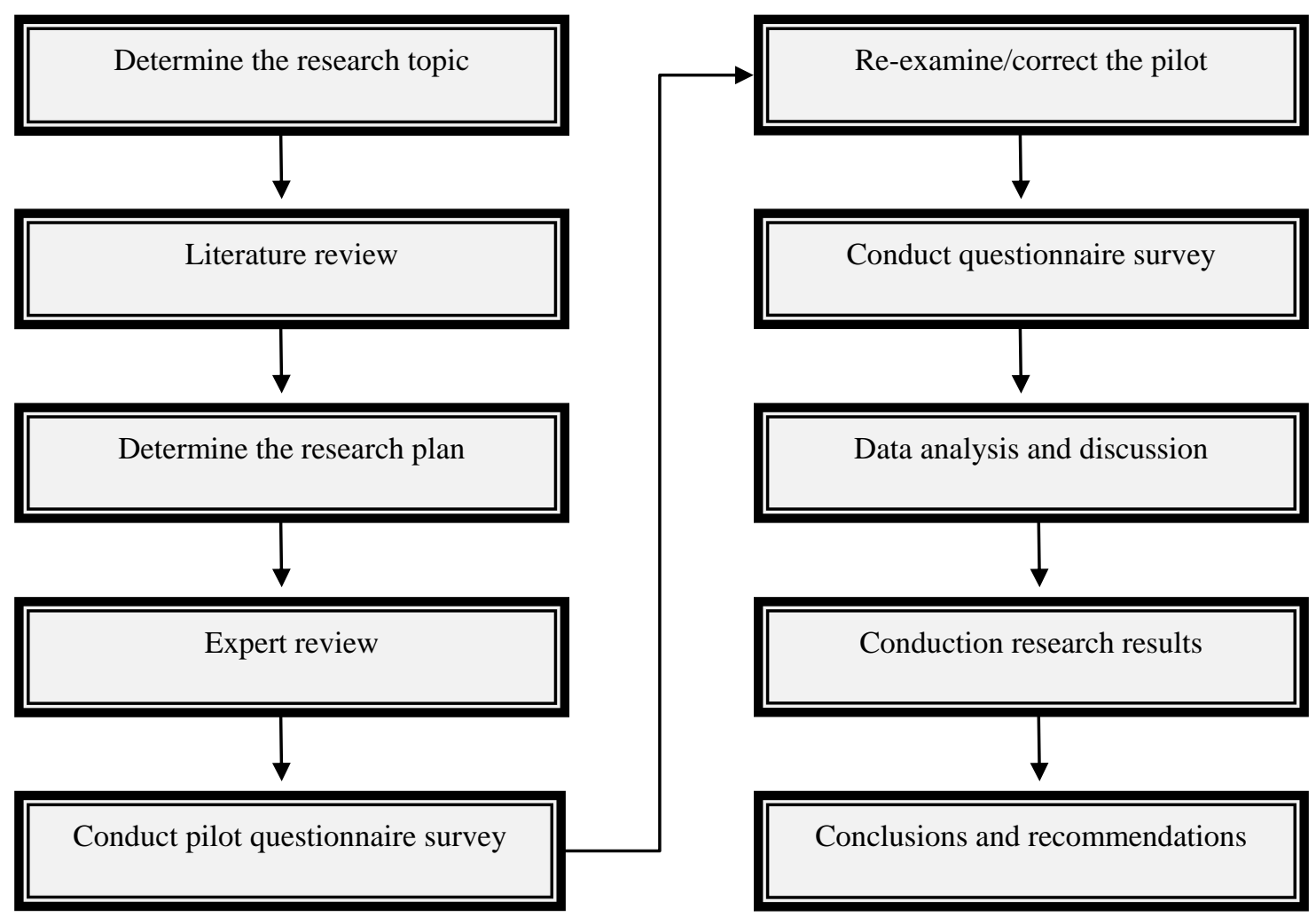

Fig. 1. Research procedures

\section{Research Population and Sample}

The population for this study comprised of 97,794, years 1 to 3 business or home economics students, from 66 Vocational High Schools in five counties/cities (i.e., Miaoli County, Taichung City, Nantou County, Changhua County and Yunlin County) in central Taiwan, which, according to the 2012 academic year statistics published by the Ministry of Education, consisted of 29 private (or foundation-funded) and 37 national (or state-funded) schools.

\section{1) Participants in the pilot questionnaire survey}


The pilot questionnaire's subjects included: 92 technical majors from the Dajia Industrial Senior High School (National), and 85 business majors and 73 home economics majors from the Chih-Yung Senior High School (Private).

\section{2) Participants in the official questionnaire survey}

To minimize errors in the study, it demanded a sample that fully represented the target populations the latter could be reasonably described by the survey results.

A "Random Proportionally stratified cluster sampling" was therefore adopted to ensure that the samples were distributed as evenly as possible between the national and private Vocational High Schools in central Taiwan.

\section{Research Tool}

After a literature review, this study compiled a questionnaire called the "Vocational High School students' perceptions of their homeroom teachers' leadership and classroom management effectiveness" as the research tool. The questionnaire was designed to use a 5-point Likert scale for its responses, and, according to the research's objectives, divided into two parts that respectively addressed the high school students' homeroom teachers' leadership and classroom management effectiveness as perceived by their students. The overall score for the "leadership" part of questionnaire, along with scores for various perspectives of leadership, were calculated in a way that a high score indicated that students' perceived good homeroom teacher leadership. On the other hand, a high score on the questionnaire's "classroom management effectiveness" section, which was based on a multi-factor scale, meant the students' perceptions of the classroom management were better.

\section{E. Establishing the Expert Content Validity}

After a study adviser did a preliminary revision, the vocational schools' experts and representatives from their electrical and electronic engineering faculties reviewed the draft questionnaire. Based on their expert advice as to the appropriateness of the questionnaire's items and wording, the draft was modified to create a pilot questionnaire with content validity.

\section{F. Implementing the Pilot Questionnaire's Survey and Result Analysis}

To ensure its appropriateness and feasibility, the draft questionnaire was put through a pilot-test immediately after it was compiled. A total of 250 pilot questionnaires were issued on January 21, 2013 to survey the participants selected through convenience sampling, namely students at the Chih-Yung Senior High School (Private) and the Dajia Industrial Senior High School (National). For enhanced validity and reliability of the research tool, returned copies of the completed pilot questionnaire were subjected to an item analysis, a factor analysis and Cronbach's $\alpha$ test using SPSS software, before the official questionnaire was finalized, which proved to have a high internal consistency with all of Cronbach's $\alpha$ values, by exceeding 90 .

\section{G. Official Questionnaire}

The pilot questionnaire was adjusted according to opinions collected from expert reviews and being put through various forms of analysis (i.e., item analysis, factor analysis and validity/reliability analysis) with any inappropriate items excluded from the questionnaire's final version.

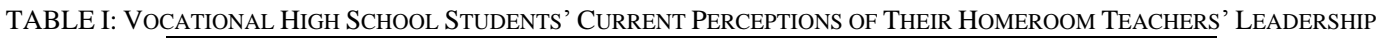

\begin{tabular}{llll}
\hline Factor & $\mathrm{M}$ & $\mathrm{SD}$ & Score \& Ranking \\
\hline Encouragement & 3.743 & .806 & 1 \\
\hline Individualized Consideration & 3.74 & .895 & 2 \\
\hline Contingent Rewards & 3.56 & .806 & 3 \\
\hline Charismatic Influence & 3.55 & .834 & 4 \\
\hline Total & 3.63 & .773 & \\
\hline
\end{tabular}

TABLE II: Vocational High SCHOOL Students' CURRENT PERCEPTIONS AS TO THE EFFECTIVENESS OF THEIR HoMEROOM TEACHERS' ClassRoOM

\begin{tabular}{llll}
\hline Factor & M & SD & Score \& Ranking \\
\hline Classroom Discipline & 3.67 & .845 & 1 \\
\hline Learning Results & 3.50 & .822 & 2 \\
\hline Teacher-student Interactions & 3.40 & .904 & 3 \\
\hline Classroom Climate & 2.92 & .869 & 4 \\
\hline Total & 3.63 & .773 & \\
\hline
\end{tabular}

\section{DATA ANALYSIS}

Data arising from responses to the questionnaire, "Vocational High School students' perceptions of their homeroom teachers' leadership and Classroom Management Effectiveness", was subjected to statistical analyses, and discussions regarding the research questions and hypotheses.
A. Vocational High School Students' Current Perceptions of Their Homeroom Teachers' Classroom Management Effectiveness

Vocational High School students' current perceptions of their homeroom teachers' leadership:

The homeroom teachers at the Vocational High Schools based in central Taiwan were perceived to display mid - to 
high-level leadership, with an overall average score of 3.63. Inthe leadership perspectives, they scored highest in encouragement, followed by individualized consideration, contingent rewards and lastly charismatic influence (3.55).

Vocational High School students' current perceptions as to the effectiveness of their homeroom teachers' classroom management:

The teachers' overall average score in effective classroom management was 3.38. Classroom discipline proved to be the top-ranked perspective of classroom management, followed by learning results, teacher-student interactions and lastly classroom climate (2.92). (Refer to Table I - Table II)

B. Demographic Differences in Vocational High School Students' Perceptions of Their Homeroom Teachers' Leadership

After considering all the perspectives, the gender differences in the students' perceptions of their homeroom teacher's leadership proved to be statistically significant $(t=-4.57, p<.001)$. Compared to their male counterparts, female students gave significantly higher scores in this area.

TABLE III: GENDER DifFERENCES IN VOCATIONAL HIGH SCHOOL STUDENTS' PERCEPTIONS OF THEIR HOMEROOM TEACHERS' LEADERSHIP

\begin{tabular}{|c|c|c|c|c|c|c|}
\hline \multirow{3}{*}{ Overall Perceived Teachers' Leadership } & Gender & Number & Average & $\begin{array}{l}\text { Standard } \\
\text { Deviation }\end{array}$ & $t$-value & $p$-value \\
\hline & Males & 668 & 3.54 & .853 & $-4.57 * * *$ & .000 \\
\hline & Females & 624 & 3.73 & .662 & & \\
\hline
\end{tabular}

TABLE IV: SENIORITY DIFFERENCES IN VOCATIONAL HIGH SCHOOL STUDENTS’ PERCEPTIONS OF THEIR HOMEROOM TEACHERS’ LEADERSHIP

\begin{tabular}{|c|c|c|c|c|c|c|c|c|c|}
\hline & $\begin{array}{l}\text { Current } \\
\text { year of } \\
\text { study }\end{array}$ & M & SD & SV & SS & $d f$ & MS & F-value & Post-hoc Test \\
\hline \multirow{2}{*}{$\begin{array}{l}\text { Average Score of } \\
\text { Perceived } \\
\text { Leadership }\end{array}$} & (2) & 3.75 & .66 & Intra-group & 746.28 & 1289 & 0.58 & .000 & \multirow{2}{*}{$(1),(2)>(3)$} \\
\hline & (3) & 3.44 & .87 & Total & 770.44 & 1291 & & & \\
\hline
\end{tabular}

$N=1,292,{ }^{* * *} P<.001 ;$ (1) 453 freshmen; (2) 430 sophomores; (3) 409 seniors

TABLE V: DifFERENT ACADEMic MAJORS’ PERCEPTIONS Within VOCATIONAL High SCHOOL STUdENTS' PERCEPTIONS OF THEIR HOMEROOM TEACHERS’ LEADERSHIP

\begin{tabular}{|c|c|c|c|c|c|c|c|c|c|}
\hline & $\begin{array}{l}\text { Academic } \\
\text { Major }\end{array}$ & M & SD & SV & SS & $d f$ & MS & $F$-value & Post-hoc Test \\
\hline \multirow{3}{*}{$\begin{array}{l}\text { Overall Perceived } \\
\text { Teachers' } \\
\text { Leadership }\end{array}$} & (1) & 3.420 & .915 & Inter-group & 33.695 & 2 & 16.85 & $29.476^{* * *}$ & \multirow[t]{3}{*}{$(2),(3)>(1)$} \\
\hline & (2) & 3.782 & .636 & Intra-group & 736.747 & 1289 & .57 & .000 & \\
\hline & (3) & 3.719 & .670 & Total & 770.442 & 1291 & & & \\
\hline
\end{tabular}

$N=1,292,{ }^{* *}{ }^{*} p<.001$; (1) 460 technical majors; (2) 455 business majors; (3) 377 home economics majors

TABLE VI: DifFERENCES BETWEEN NATIONAL AND PRIVATE SCHOOLS IN VOCATIONAL High SCHOOL STUDENTS’ PERCEPTIONS OF THEIR HOMEROOM TEACHERS' LEADERSHIP

\begin{tabular}{|c|c|c|c|c|c|c|c|}
\hline & & National/Private School & Number & Average & $\begin{array}{l}\text { Standard } \\
\text { Deviation }\end{array}$ & $t$-value & $p$-value \\
\hline \multirow[t]{2}{*}{$\begin{array}{l}\text { Overall Perceiv } \\
\text { Leadership }\end{array}$} & Teachers' & National & 668 & 3.58 & .717 & $-1.997^{*}$ & .046 \\
\hline & & Private & 624 & 3.66 & .798 & & \\
\hline
\end{tabular}

TABLE VII: GENDER DifFERENCES IN VOCATIONAL HIGH SCHOOL STUDENTS’ PERCEPTIONS OF THE EFFECTIVENESS OF THEIR HOMEROOM TEACHERS' CLASSROOM MANAGEMENT

\begin{tabular}{|c|c|c|c|c|c|c|}
\hline & Gender & Number & Average & Standard Deviation & $t$-value & $p$-value \\
\hline \multirow{2}{*}{$\begin{array}{l}\text { Overall Perceived Classroom } \\
\text { Management Effectiveness }\end{array}$} & Males & 668 & 3.296 & .727 & \multirow[b]{2}{*}{$-4.859 * * *$} & \multirow[b]{2}{*}{.000} \\
\hline & Females & 624 & 3.474 & .590 & & \\
\hline
\end{tabular}

$N=1,292,{ }^{*} p<.05, * * * p<.001$

After considering all the perspectives, there were significant statistical seniority-based differences in how students perceived their homeroom teachers' leadership $(F=20.87, p<.001)$, as shown in Table 4. Compared to the seniors, the freshmen and sophomore students gave significantly higher scores to their teachers' leadership, despite the insignificant differences between freshmen and sophomores.

After considering all perspectives, there were significant statistical differences in the various academic majors at to how students perceived their homeroom teachers' leadership, $(F=29.479, p<.001)$, as shown in Table V. Compared to the 
home economics and technical majors, business majors gave their teachers higher scores for the individualized consideration leadership perspective. As for the charismatic influence, encouragement and contingent rewards perspectives and the overall classroom management, both the business and home economics majors gave their teachers higher scores than the technical majors.

TABLE VIII: SENIORITY DIFFERENCES IN VOCATIONAL High SCHOOL STUDENTS' PERCEPTIONS OF THE EFFECTIVENESS OF TheIR HOMEROOM TEACHERS' ClassRoOM MANAGEMENT

\begin{tabular}{|c|c|c|c|c|c|c|c|c|c|}
\hline & $\begin{array}{c}\text { Current year of } \\
\text { study }\end{array}$ & M & SD & SV & SS & $d f$ & MS & $F$-value & $\begin{array}{c}\text { Post-hoc } \\
\text { Test }\end{array}$ \\
\hline \multirow{2}{*}{$\begin{array}{l}\text { Overall } \\
\text { Perceived } \\
\text { Classroom }\end{array}$} & (1) & 3.42 & .67 & Inter-group & 7.72 & 2 & 3.86 & $8.71 * * *$ & \multirow{3}{*}{$\begin{array}{l}(1), \quad(2)> \\
(3)\end{array}$} \\
\hline & (2) & 3.45 & .61 & Intra-group & 571.46 & 1289 & 0.44 & .000 & \\
\hline $\begin{array}{l}\text { Management } \\
\text { Effectiveness }\end{array}$ & (3) & 3.27 & .71 & Total & 579.18 & 1291 & & & \\
\hline
\end{tabular}

$N=1,292,{ }^{* *}{ }^{*} p<.001 ;(1)$ freshmen; (2) sophomores ; (3) seniors

TABLE IX: ACADEMIC MAJOR-ORIENTED DiFFERENCES IN VOCATIONAL HiGH SCHOOL STUdENTS' PERCEPTIONS OF THE EFFECTIVENESS OF THEIR HOMEROOM TEACHERS' ClaSSROOM MANAGEMENT

\begin{tabular}{|c|c|c|c|c|c|c|c|c|c|}
\hline & $\begin{array}{l}\text { Academic } \\
\text { Major }\end{array}$ & M & SD & SV & SS & $d f$ & MS & $F$-value & $\begin{array}{c}\text { Post-hoc } \\
\text { Test }\end{array}$ \\
\hline $\begin{array}{l}\text { Overall Perceived } \\
\text { Classroom }\end{array}$ & (1) & 3.20 & 0.75 & Inter-group & 24.31 & 2 & 12.15 & $28.24 * * *$ & \multirow[t]{3}{*}{$\begin{array}{l}(2),(3)> \\
(1)\end{array}$} \\
\hline Management & $(2)$ & 3.50 & 0.59 & Intra-group & 554.88 & 1289 & 0.43 & .000 & \\
\hline Effectiveness & (3) & 3.46 & 0.61 & Total & 579.18 & 1291 & & & \\
\hline
\end{tabular}

$N=1,292, * * * p<.001$; (1) Technical majors; (2) Business majors; (3) Home economics majors

TABLE X: DifFERENCES BETWEEN NATIONAL AND PRIVATE SCHOOLS IN VOCATIONAL High SCHOOL STUDENTS' PERCEPTIONS OF THE EFFECTIVENESS OF THEIR HOMEROOM TEACHERS' CLASSROOM MANAGEMENT

\begin{tabular}{|c|c|c|c|c|c|c|c|}
\hline & & $\begin{array}{l}\text { National/Private } \\
\text { School }\end{array}$ & Number & Average & $\begin{array}{l}\text { Standard } \\
\text { Deviation }\end{array}$ & $t$-value & $p$-value \\
\hline \multirow{2}{*}{$\begin{array}{l}\text { Overall } \quad \text { Perceived } \\
\text { Management Effectiveness }\end{array}$} & Classroom & National & 432 & 3.313 & .657 & \multirow{2}{*}{$-2.616^{* * *}$} & \multirow{2}{*}{.009} \\
\hline & & Private & 860 & 3.417 & .674 & & \\
\hline
\end{tabular}

$N=1,292, * * p<.01, * * * p<.001$

After considering all the perspectives, there was a significant statistical difference between the national and private schools in the students' perceptions of their homeroom teachers' leadership $(t=-1.997, p<.05)$. In other words, private school teachers had significantly higher leadership scores than their counterparts in the national schools.

\section{Demographic Differences in Vocational High School Students' Perceptions of Their Homeroom Teachers' Classroom Management Effectiveness}

After considering all the perspectives, there was a significant statistical gender difference in how students perceived their homeroom teachers' classroom management effectiveness $(t=-4.859, p<.001)$. In other words, female students gave significantly higher scores than the male students.

After considering all the perspectives, there were significant statistical seniority-oriented differences in how students perceived the effectiveness of their homeroom teachers' classroom management $(F=8.711, p<.001)$. In other words, students with different levels of seniority had significant disagreements over the effectiveness of their teachers' classroom management.

After considering all the perspectives, there were significant statistical differences between academic majors in how students perceived the effectiveness of their homeroom teachers' classroom management $(F=28.235, p<.001)$. In other words, students with different academic majors disagreed significantly over the effectiveness of their teachers' classroom management.

After considering all the perspectives, there was a significant statistical difference between national and private schools in how students perceived the effectiveness of their homeroom teachers' classroom management ( $t=-2.616$, $p<.01)$. That is, the private schools' homeroom teachers scored higher in classroom management skills than their national-school counterparts.

\section{CONCLUSIONS AND RECOMMENDATIONS}

\section{A. Conclusions}

1) Homeroom teachers in central Taiwan's Vocational High Schools usually enhanced their leadership through encouragement but seldom through charismatic influence.

2) Among all perspectives of classroom management effectiveness, the aforementioned teachers were best in 
classroom discipline but needed to improve the classroom climate.

3) In the demographic subgroups, the female freshmen and sophomores majoring in business or home economics at the aforementioned private schools had the most favorable perceptions of their homeroom teachers' leadership.

- Compared to national school students, the private school students had more favorable perceptions of their homeroom teachers' leadership.

- Compared to technical majors, the business and home economics majors had more favorable perceptions of their homeroom teachers' leadership.

- Compared to senior students, the freshmen and sophomores had more favorable perceptions of their homeroom teachers' leadership.

- Female students had more favorable perceptions of their homeroom teachers' leadership than the male students.

4) In the demographic subgroups, the female freshmen and sophomores majoring in business or home economics, at the aforementioned private schools, had the most favorable perceptions of the effectiveness of their homeroom teachers' classroom management.

- Compared to the national school students, the private school students had more favorable perceptions as to the effectiveness of their homeroom teachers' classroom management.

- Compared to technical majors, the business and home economics majors had more favorable perceptions as to the effectiveness of their homeroom teachers' classroom management.

- Compared to senior students, freshmen and sophomores had more favorable perceptions as to the effectiveness of their homeroom teachers' classroom management.

- Female students had more favorable perceptions as to the effectiveness of their homeroom teachers' classroom management than the male students.

\section{B. Recommendations}

1) It is recommended that the administrative staff of Vocational High Schools need to...

- Implement teacher workshops, or seminars, concerning classroom management on a regular basis.

- Step up their efforts in offering teachers programs on leadership development.

2) It is recommended that homeroom teachers at Vocational High Schools need to..

- Build satisfactory teacher-student relationships.

- Take the initiative and demonstrate care and concern for their students.

- Fulfill their potential as a leader through charismatic influence.

- Effectively enhance the classroom climate.

- Make continuous, extensive learning efforts to sharpen their leadership skills.

- Stay committed to managing and leading senior year classes.

This study was conducted two months prior to graduation, when the senior year students were making momentous decisions, such as pursuing a college degree or a career, and

consequently, were both anxious and anticipative about their future. It is imperative that homeroom teachers find out what their students need, and demonstrate a sincere concern for them. To assist students in career planning, they should provide information or access to counseling services, with regards to colleges and the job market. In other words, homeroom teachers are expected to help students understand themselves, and how they can place themselves in a position for success while aiming for the right goals.

Meanwhile, the senior students' homeroom teachers are advised to improve their leadership skills, either by involving the whole class in ingenious, creative and nonconventional initiatives, or by creating a pleasant classroom climate through collective student effort, so that school days can be fun-filled and exciting rather than boring and monotonous. An innovative homeroom teacher continuously and vigorously dedicated to the senior-year students' wellbeing can aid in their career planning, while at the same time enhancing not only the teacher-student bond, but also the students' perceptions of his/her leadership and classroom management skills.

\section{REFERENCES}

[1] X. M. Zhang, “An experimental study of improving elementary school teachers' classroom management knowledge and practice," Journal of Pingtung Teachers College, vol. 10, pp. 65-95, 1996.

[2] M. J. Chen, "The practical approach of teacher education from the influence of classroom management strategies to teaching effectiveness," Journal of Educational Research and Development, vol. 2, no. 1, pp. 34-62, 2006

[3] Y. L. Liang, The Study of Organizational Commitment and Classroom Management Effectiveness of Public Senior High School Homeroom Teacher in Central Taiwan, Changhua County: Department of Industrial Education and Technology, National Changhua University of Education, 2011.

[4] B. M. Bass, Leadership and performance beyond expectations, New York: The free Press, 1985.

[5] M. Y. Chen, A Study of the Relationships among Leading Teachers Leadership Behavior and Classroom Management Effectiveness of the Technical Program Students in Senior High School in Taiwan, Changhua County: Department of Industrial Education and Technology, National Changhua University of Education, 2004.

[6] C. J. Huang, Relation among Vocational High School Homeroom Teachers' Leadership Behavior, Class Atmosphere and Learning Satisfaction-A Case Study in Changhua County, Changhua County: Department of Industrial Education and Technology, National Changhua University of Education, 2007.

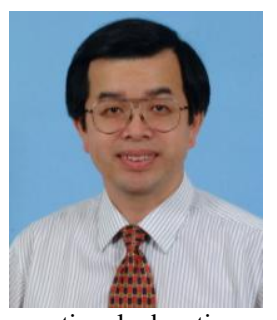

vocational education.

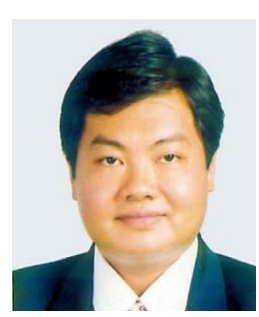

Chin-Chang Wu received M.S. in education from National Changhua University of Education, Taiwan, R.O.C. and Ph.D in industrial education and technology from National Changhua University of Education in 2005. He has been a school principal in Dong-Shing Elementary School, Taiwan, R.O.C. and dealt with administrative affairs of the school. His research interests include leading, technology, and

Fang-Pin Lai received M.S. degree at the Department of Industry Education from National Taiwan Normal University in 1994, and currently is a doctoral student of the Department of Industrial Education and Technology at National Changhua University of Education (NCUE), Taiwan, R.O.C. 


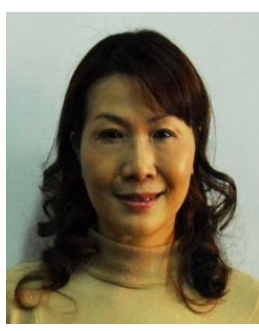

Hui-Yi Pai is dedicating her life in fine arts, and is pursuing her Ph.D. in Natioanl Changhua University of Education.

She has had eight solo exhibitions all over the world including the recent one in Vancouver, Canada and a publication: Flash Back. Ms. Pai is the recipient of several awards such as French Art Salon collection award, International Japan FIA Art Exibition award, Taiwan Art Exhibition collection award, YuShan Art Exhibition collection award, Tai-Yang Art Exhibition award, Da Dung Fine Arts Exhibition award, Central Taiwan Art Exhibition award and Tea Township Thousand people outdoor sketching.

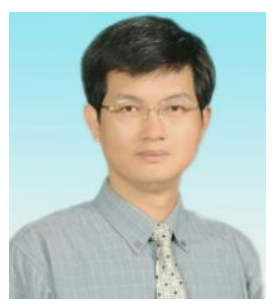

Chin-Wen Liao received his M.S. and Ph.D. degrees in industrial education from National Taiwan Normal University, Taiwan, R.O.C. in 1994 and 2002, respectively. Since August 2011, he has been a professor in the Department of Industrial Education and Technology at National Changhua University of Education (NCUE) in Taiwan, R.O.C. He teaches courses in technology and vocational education, energy education, course and teaching, organizational learning. His research interests include technology and vocational education, teacher education, energy education of technology, and learning organization. 